\title{
Effects of Coronavirus Disease 2019 (COVID-19) on peripheral blood lymphocytes and their subsets in children: imbalanced $\mathrm{CD} 4+/ \mathrm{CD} 8+\mathrm{T}$ cell ratio and disease severity
}

\author{
Shima Mahmoudi ${ }^{1}$, Bahareh Yaghmaei ${ }^{1}$, Meisam Sharifzadeh Ekbatani ${ }^{1}$, Babak \\ Pourakbari $^{1}$, Amene Navaeian ${ }^{1}$, Nima Parvaneh ${ }^{1}$, Mohammad Taghi Haghi Ashtiani ${ }^{1}$, and \\ Setareh Mamishi ${ }^{1}$ \\ ${ }^{1}$ Affiliation not available
}

July 7,2020

\begin{abstract}
Although the pathogenesis of Coronavirus Disease 2019 (COVID-19) is not fully described, the interaction between the SARSCoV-2 and the immune system is so complicated, and lymphopenia, hyper-inflammatory responses, and cytokines play an essential role in the pathology of COVID-19. Among the laboratory features of COVID-19, some hematological abnormalities have been described; however, no studies about lymphocyte subset analyses have been reported in children. Therefore, this study aimed to explain the characteristics of lymphocyte subsets in pediatrics with mild or severe COVID-19. Subjects of the study were children with confirmed severe acute respiratory syndrome coronavirus 2 (SARS-CoV-2) pneumonia by real-time RT-PCR admitted to the Children's Medical Center, affiliated to the Tehran University of Medical Sciences. Complete blood count and lymphocyte subpopulations were studied for all patients. The study population included 55 hospitalized patients with confirmed SARS-CoV-2 infection (34 patients (62\%) with mild and 21 patients (38\%) with severe disease). Lymphocyte counts were significantly lower in patients with severe disease (mean $\pm \mathrm{sd} 1.6 \pm 0.9$ in the severe group vs. $2.3 \pm 2.2$ in the mild group). Compared with mild pneumonia, children with severe pneumonia had a higher count of CD8+ lymphocyte, while a lower percentage of CD4+ lymphocyte was observed; however, the differences were not significant. Interestingly, severe group had a significantly lower $\mathrm{CD} 4+/ \mathrm{CD} 8+\mathrm{T}$ cell ratio compared to the mild group $(1.1 \pm 0.47$ vs. $1.4 \pm 0.8$, p-value: 0.039$)$. $\mathrm{CD} 4+/ \mathrm{CD} 8+$ less than 2, 1.5, and 1 was found in 48 (87\%), 40 (73\%), and 19 cases (35\%). Among 7 cases (13\%) who died, $100 \%$ had $\mathrm{CD} 4+/ \mathrm{CD} 8+$ ratio $<2,86 \%$ had $\mathrm{CD} 4+/ \mathrm{CD} 8+$ ratio $<1.5$, and $29 \%$ had $\mathrm{CD} 4+/ \mathrm{CD} 8+$ ratio $<1$. Lymphocyte counts and lymphocyte subset (CD4+/CD8 $+\mathrm{T}$ cell ratio) reflect the disease severity, which can be considered as a potential predictor for disease severity of COVID-19 in children.
\end{abstract}

\section{Introduction}

The Coronavirus Disease 2019 (COVID-19) caused by severe acute respiratory syndrome corona virus 2 (SARS-CoV-2) has rapidly spread in China and around the world and is still on-going (Sohrabi, Alsafi et al. 2020). All people, including children are susceptible to SARS-CoV-2, and a rapid progression in morbidity and mortality rate due to human-to-human transmission of the virus are still reported (Lotfi and Rezaei 2020).

Although the pathogenesis of COVID-19 is not fully described, the interaction between the SARS-CoV-2 and the immune system is so complicated, and lymphopenia, hyper-inflammatory responses, and cytokines play an important role in the pathogenesis of COVID-19 (Saghazadeh and Rezaei 2020, Yazdanpanah, Hamblin et al. 2020).

Recent studies suggest that the SARS-CoV-2 infection may primarily affect $\mathrm{T}$ lymphocytes, particularly 
$\mathrm{CD}^{+} \mathrm{T}$ and $\mathrm{CD} 8^{+} \mathrm{T}$ cells, which might be highly involved in the pathological process of COVID-19 (Henry, de Oliveira et al. 2020, Wang, Hu et al. 2020).

$\mathrm{CD}^{+}$and $\mathrm{CD}^{+}{ }^{+} \mathrm{T}$ cells play a fundamental role in controlling viral infections maintaining cellular and humoral immune responses. These cells are involved in humoral and cytotoxic immunity against viral infections. $\mathrm{CD} 4^{+} \mathrm{T}$ cells have multiple roles and are required to support $\mathrm{CD} 8^{+} \mathrm{T}$ cell responses. Moreover, these cells help to B cells to elicit antibody responses ( $\mathrm{Ng}$, Snell et al. 2013). CD8 ${ }^{+} \mathrm{T}$ cells have been shown to play a critical role in mediating viral clearance after acute viral respiratory infections, including respiratory syncytial virus, influenza A virus, and human metapneumovirus (Wang, Nie et al. 2020).

Among the laboratory features of COVID-19, a number of hematological abnormalities have been described (Henry, de Oliveira et al. 2020); however, no studies about lymphocyte subset analyses have been reported in children. Therefore, it is important to explain the characteristics of lymphocyte subsets in pediatrics with mild or severe COVID-19. This study aimed to evaluate the lymphocyte subsets in 55 laboratory-confirmed cases of SARS-CoV-2.

\section{Material and methods}

This study received ethical approval from the Tehran University of Medical Sciences, Tehran, Iran. All participants gave written informed consent, and the study was carried out following the Declaration of Helsinki.

\section{Patient selection}

Subjects of the study were children with confirmed SARS-CoV-2 pneumonia by real-time RT-PCR (admitted between 07 March and 10 June 2020) in Children's Medical Center, an Iranian referral hospital who underwent the detection of peripheral blood lymphocyte subsets. The following information on each patient was extracted from electronic medical records: age, sex, underlying disease, intensive care unit (ICU) admission, need for invasive mechanical ventilation, laboratory findings, chest computed tomography (CT), and mortality. Chest CT scan was reported by an expert radiologist, and abnormal CT finding was considered if typical CT imaging features for COVID-19 including peripheral, bilateral, ground-glass opacification with or without consolidation or visible intralobular lines, multifocal ground-glass opacification or rounded morphology with or without consolidation or visible intralobular lines, or reverse halo sign or other findings of organizing pneumonia were reported (Simpson, Kay et al. 2020). On admission, severe illness was defined according to the following criteria: (1) breathing rate [?]30 times/min; (2) pulse oximeter oxygen saturation $\left(\mathrm{SpO}_{2}\right)$ [?] $93 \%$ at rest; and (3) ratio of the partial pressure of arterial oxygen $\left(\mathrm{PaO}_{2}\right)$ to the fraction of inspired oxygen $\left(\mathrm{FiO}_{2}\right)$ [?]300 $\mathrm{mmHg}$ (Wang, Nie et al. 2020).

\section{Real-time RT-PCR for SARS-CoV-2}

In all cases, nasopharyngeal samples were collected and tested for SARS-CoV-2 with the LightMix@ Modular Wuhan CoV RdRP-gene Kit (53-0777-96) by TIB MOLBIOL, Berlin, Germany (https://www.roche-as.es). The rRT-PCR assay was performed according to the manufacturer's protocol using probe P1 from the WHO protocol (RdRP_SARSr-P1: FAM-CCAGGTGGWACRTCATCMGGTGATGC-BBQ). The rRT-PCR assay was performed following recommended cycling conditions: reverse transcription at $55{ }^{\circ} \mathrm{C}$ for 5 min and 95 ${ }^{\circ} \mathrm{C}$ for $5 \mathrm{~min}$, followed by 45 cycles of PCR at $95{ }^{\circ} \mathrm{C}$ for $15 \mathrm{sec}$ and $60{ }^{\circ} \mathrm{C}$ for $15 \mathrm{sec}$. The cycle threshold (Ct) value above 39.0 was considered negative. The tested sample was considered SARS-CoV-2 positive if LightMix showed positive results for the RdRP gene.

\section{Flow Cytometry for determination of lymphocyte subsets}

Lymphocyte subsets were detected by flow cytometry analysis. Samples of EDTA anticoagulated peripheral blood $(2 \mathrm{~mL})$ were collected from patients with COVID-19 before initiation of treatment. All samples were tested within 6 hours of being obtained, and $\mathrm{CD} 4^{+}$and $\mathrm{CD} 8^{+} \mathrm{T}$-cell counts (cells/ $\mu \mathrm{L}$ ) were measured by 
multiple-color flow cytometry. The cells were analyzed on a BD FACS Canto II flow cytometry system (BD Biosciences).

\section{Statistical analysis}

Statistical analysis was performed with the Statistical Package for the Social Sciences (SPSS version 18.0, SPSS Inc., Chicago, IL, USA).

Categorical data were described as percentages and continuous data as median with interquartile range (IQR). Normally distributed continuous variables were presented as means with standard deviations (SD). Comparison of the differences between the two groups was conducted using the t-test, Chi-square test, or Mann-Whitney U test. Variables with a two-tailed p-value $<0.05$ were considered statistically significant.

\section{Results}

\section{Baseline data}

The study population included 55 hospitalized patients with confirmed SARS-CoV-2 infection. The age of patients ranged from 20 days to 14.0 years $(6.9 \pm 4.1)$. Thirty-four patients (17 males and 17 females) with a mean age of $6.9 \pm 3.9$ years had mild infection, and 21 patients (17 males and 4 females) with a mean age of $7.0 \pm 4.5$ years were included in the severe group. The severe form of the disease was significantly higher in males than females ( $81 \%$ vs. $19 \%$, p value $=0.02$ ).

Among all patients, 9 cases admitted to the ICU, and 7 of them had severe pneumonia ( $33 \%$ in severe group and $6 \%$ in mild group, $\mathrm{p}$ value $=0.02)$. Three patients received invasive mechanical ventilation. The presence of underlying diseases was significantly higher in cases with severe disease than cases in mild group $(67 \%$ vs. $29 \%$, p value $=0.011)$. Abnormal CT finding was found in $89 \%$ and $67 \%$ of cases with severe and mild disease, respectively $(\mathrm{p}$ value $=0.14)$. The mortality was $13 \%(\mathrm{n}=7)$, and 6 deaths $(86 \%)$ occurred among cases with severe disease.

\section{Laboratory findings}

Inflammatory indicators; erythrocyte sedimentation rate (ESR) and C-reactive protein (CRP) were abnormal in $17(85 \%)$, and $17(80 \%)$ patients in severe and 25 (81\%), and 24 (71\%) patients in mild group.

In blood tests of cases with severe pneumonia, leukocytes, lymphocytes, and neutrophils were below the normal range in 3 (14\%), $6(29 \%)$, and 2 (9\%) patients, and above the normal range in $3(15 \%), 0(0 \%)$, and $5(24 \%)$ patients, respectively. In another group with mild pneumonia elevated leukocytes, lymphocytes, and neutrophils counts were seen in $6(18 \%), 1(3 \%)$, and $7(21 \%)$ patients, while it was below the normal range in $4(12 \%), 13(38 \%)$, and $3(9 \%)$ patients, respectively. There were no significant differences in white blood cell (WBC) count, Red Blood Cells (RBC), hemoglobin, platelet, and neutrophil count between the two groups. Lymphocyte count was significantly lower in patients with severe disease (mean \pm sd $1.6 \pm 0.9$ in the severe group vs. $2.3 \pm 2.2$ in the mild group) (Table1).

\section{Lymphocyte subsets in peripheral blood of patients}

According to the results of each index, $\mathrm{CD} 4^{+} \mathrm{T}$ and $\mathrm{CD} 8^{+} \mathrm{T}$ cells were divided into below the normal values, within the normal value and above the normal values. The corresponding quantities and proportions were respectively calculated based on age, and the results were shown in Table 2.

Compared with mild pneumonia children, patients with severe pneumonia had a higher count of CD8 ${ }^{+}$ lymphocyte, while a lower percentage of $\mathrm{CD} 4^{+}$lymphocyte was observed. However, there were no significant differences in the percentage of $\mathrm{CD}^{+}$and $\mathrm{CD} 8^{+}$lymphocytes between the two groups ( $\mathrm{p}$-value $=0.3$ and $\mathrm{p}$-value $=0.4$, respectively) (Figure 1). 


\section{$\mathrm{CD}^{+} / \mathrm{CD}^{+} \mathrm{T}$ cell ratio and COVID-19 Severity}

Interestingly, the severe group had a significantly lower $\mathrm{CD} 4^{+} / \mathrm{CD} 8^{+} \mathrm{T}$ cell ratio compared to the mild group $(1.1 \pm 0.47$ vs. $1.4 \pm 0.8, \mathrm{p}$ value: 0.039$)$ (Figure 1$)$.

$\mathrm{CD}^{+} / \mathrm{CD}^{+}$less than 2, 1.5, and 1 was found in $48(87 \%), 40(73 \%)$, and 19 cases $(35 \%)$, respectively. The frequency of an inverted $\mathrm{CD} 4^{+} / \mathrm{CD} 8^{+}$ratio increased with age. A ratio $<1$ was seen in $32 \%$ of patients less than 5 years $(n=6)$ and in $68 \%$ of 5 - to 15 -year-olds $(n=13)$. Males were more likely to have a decreased ratio than females (Table 3 ).

Among 7 cases who died, $100 \%$ had $\mathrm{CD} 4^{+} / \mathrm{CD} 8^{+}$ratio $<2,86 \%$ had $\mathrm{CD} 4^{+} / \mathrm{CD} 8^{+}$ratio $<1.5$, and $29 \%$ had $\mathrm{CD} 4^{+} / \mathrm{CD} 8^{+}$ratio $<1$.

\section{Discussion}

To our knowledge, this is the first preliminary study evaluating the lymphocyte subset characteristics of children with laboratory-confirmed SARS-CoV-2 infection.

Although early studies reported that children were less likely to develop COVID-19 than other age groups, recent studies revealed that children are at a similar risk of infection to the general population (Bi, Wu et al. 2020, Lotfi and Rezaei 2020). Consistent with previous reports (Dong, Mo et al. 2020, Guan, Ni et al. 2020, Sun, Li et al. 2020, Tang, Wu et al. 2020), the present study showed a male predominance in the incidence of COVID-19.

Changes in the immune system may result in decreased immune function and increased incidence of severity, morbidity, and mortality of infections $(1,2)$. According to the laboratory findings, normal leukocytes counts were more common in both cases with severe and mild disease that was similar to the previous report in children (Bai, Liu et al. 2020). It has been hypothesized that the repletion of lymphocytes plays a vital role in the recovery of patients with COVID-19 (Henry 2020). Lymphopenia and inflammatory cytokine storm during highly pathogenic coronavirus infections, such as SARS coronavirus (SARS-CoV), MERS coronavirus (MERS-CoV), and SARS COV-2 infections might be associated with disease severities (Yang, Li et al. 2020).

Although $63 \%-84.6 \%$ of adult patients with severe diseases have lymphopenia (Guo, Cao et al. 2020, Liu, Li et al. 2020), in our study, lymphopenia was found in 19 children (34.5\%). Lymphocyte count was significantly lower in patients with severe disease. So, a significant decrease in lymphocytes may signify clinical worsening and increased risk of a poor outcome. According to previous reports in children with probable or suspected SARS (Bitnun, Allen et al. 2003, Hon, Leung et al. 2003), total lymphopenia was common and more prominent in older children with more severe disease. The counts of total leukocytes, RBCs, platelets, and neutrophils were not significantly different in severe and mild groups.

Inflammatory markers, including CRP and ESR, were higher in severe cases than in mild cases, demonstrating a higher inflammatory state during severe infection. Since cytokine storm is associated with apoptosis of lymphocytes, a decrease in number of peripheral lymphocytes in severe cases is probable (Ni, Tian et al. 2020).

Although an apparent decrease in peripheral lymphocytes in COVID-19 patients has been reported, alteration in the T cells subsets is still unclear (Wang, Nie et al. 2020, Zhang, Zhao et al. 2020). However, it has been reported that $\mathrm{CD} 4^{+} \mathrm{T}$ cells and $\mathrm{CD} 8^{+} \mathrm{T}$ cells decreased in severe cases of COVID-19 than mild cases (Liu, Li et al. 2020, Ni, Tian et al. 2020, Wang, Nie et al. 2020). In our study higher number of CD8 ${ }^{+} \mathrm{T}$ cells was documented in the severe group than mild cases. The $\mathrm{CD} 4^{+}$lymphocytopenia was more prevalent in the severe group than the mild group (38\% vs. $29 \%)$. On the other hand, higher percentage of CD $8^{+} \mathrm{T}$ cells was found in the severe group (29\%) than in the mild group (18\%); however, these differences were not significant. In the study of Bai et al. (Bai, Liu et al. 2020), Among 25 asymptomatic cases, very mild cases, 23 cases had normal $\mathrm{CD} 8^{+} \mathrm{T}$ lymphocyte counts, while increased $\mathrm{CD} 8^{+} \mathrm{T}$ lymphocyte counts were mildly increased in two cases $(8 \%)$. 
Progressive loss of CD4 ${ }^{+} \mathrm{T}$ cells and an increase in $\mathrm{CD} 8^{+} \mathrm{T}$ cells are consistent features of HIV-1 infection. It has been reported that $\mathrm{CD} 8^{+} \mathrm{T}$ cells' count may change slightly, while the $\mathrm{CD} 4^{+} \mathrm{T}$ cells count decline at inconstant rate. A progressive decline in $\mathrm{CD} 4^{+} \mathrm{T}$ cells, as well as a rise in $\mathrm{CD} 8^{+} \mathrm{T}$ cells, suggests a compensatory rise in $\mathrm{CD} 8^{+} \mathrm{T}$ cells in response to a decline in $\mathrm{CD} 4^{+} \mathrm{T}$ cells (Margolick, Munoz et al. 1995).

Although lymphocyte count, especially $\mathrm{CD} 4^{+}$, has been reported as a clinical predictor of severity of disease (Henry, de Oliveira et al. 2020), in our study, no significant differences between CD4 ${ }^{+} \mathrm{T}$ cells and CD8 ${ }^{+} \mathrm{T}$ cells and severity of disease were found. On the other hand, the $\mathrm{CD} 4^{+} / \mathrm{CD} 8^{+} \mathrm{T}$ cell ratio was significantly lower in those patients with severe disease compared to those with mild disease. In contrast to previous reports in adults that absolute numbers of total $\mathrm{T}$ lymphocytes, $\mathrm{CD} 4^{+} \mathrm{T}$ cells, and $\mathrm{CD} 8^{+} \mathrm{T}$ cells were reduced below the lower limit of normal in the vast majority of patients with either severe or moderate COVID-19 (Wang, Hu et al. 2020), we demonstrated that percentage of $\mathrm{CD} 4^{+} \mathrm{T}$ cells, and $\mathrm{CD} 8^{+} \mathrm{T}$ cells were reduced below the lower limit of normal in $29 \%$ and $38 \%$ of cases with mild and severe COVID-19, respectively. However, $\mathrm{CD} 8^{+} \mathrm{T}$ cells were reduced below the lower limit of normal in $12 \%$ and $5 \%$ of cases with mild and severe COVID-19, respectively.

The low frequency of lymphopenia in severe patients is mainly related to the significantly decreased absolute counts of $\mathrm{T}$ cells, especially CD8 ${ }^{+} \mathrm{T}$ cells (Liu, Li et al. 2020), therefore; low rate of lymphopenia in children might be due to the fact that a majority of children have normal or even elevated $\mathrm{CD} 8^{+} \mathrm{T}$, cell counts.

The normal $\mathrm{CD}^{+} / \mathrm{CD}^{+}$ratio in healthy hosts is poorly defined. Ratios between 1.5 and 2.5 are generally considered normal (McBride and Striker 2017). Low $\mathrm{CD}^{+} / \mathrm{CD} 8^{+}$ratios mainly observe in HIV. However, a low or inverted $\mathrm{CD} 4^{+} / \mathrm{CD} 8^{+}$ratio is associated with systemic lupus erythematosus, chronic inflammation, and cytomegalovirus infection as well (Maeda 1999, McBride and Striker 2017). CD8 ${ }^{+} \mathrm{T}$ cells represent an important immunological component of protection against viral infections. Cytomegalovirus has a significant impact on the $\mathrm{CD} 4^{+} / \mathrm{CD} 8^{+}$ratio by increasing circulating $\mathrm{CD} 8^{+}$cells in response to the infection (RekerHadrup, Strindhall et al. 2006).

Inversion of the $\mathrm{CD}^{+} / \mathrm{CD}^{+}$ratios are associated with poor survival (Huppert, Pinto et al. 2003), a link between low ratio and poor outcomes observed in our study, and importantly $86 \%$ of death rates (n=6) was reported in cases with low $\mathrm{CD} 4^{+} / \mathrm{CD} 8^{+}$ratios $(<1.5)$.

A decrease in $\mathrm{CD} 4^{+} / \mathrm{CD} 8^{+}$ratio indicates the extent of the impairment of the immune system by COVID19. Therefore, a decline in $\mathrm{CD} 4^{+} / \mathrm{CD} 8^{+} 8$ ratio may serve as a useful factor to reflect the derangement of immune responses and even death in patients with severe COVID-19.

In conclusion, lymphocyte counts and inverted $\mathrm{CD} 4^{+} / \mathrm{CD} 8^{+} \mathrm{T}$ cell ratio can be considered as a potential predictor for disease severity of COVID-19.

\section{Acknowledgments}

The authors would like to thank the patients who participated in this study, and the staff at Children's Medical Center for their assistance with study enrollment, data collection, and sample examination.

\section{Conflict of interests}

The authors declare that there is no conflict of interest.

Availability of data: The data that support the findings of this study are available on request from the corresponding author. The data are not publicly available due to privacy or ethical restrictions.

\section{References}

Bai, K., W. Liu, C. Liu, Y. Fu, J. Hu, Y. Qin, Q. Zhang, H. Chen, F. Xu and C. Li (2020). "Clinical Analysis of 25 COVID-19 Infections in Children." Pediatr Infect Dis J39 (7): e100-e103.

Bi, Q., Y. Wu, S. Mei, C. Ye, X. Zou, Z. Zhang, X. Liu, L. Wei, S. A. Truelove and T. Zhang (2020). "Epidemiology and transmission of COVID-19 in 391 cases and 1286 of their close contacts in Shenzhen, 
China: a retrospective cohort study." The Lancet Infectious Diseases.

Bitnun, A., U. Allen, H. Heurter, S. M. King, M. A. Opavsky, E. L. Ford-Jones, A. Matlow, I. Kitai, R. Tellier and S. Richardson (2003). "Children hospitalized with severe acute respiratory syndrome-related illness in Toronto." Pediatrics112 (4): e261-e261.

Dong, Y., X. Mo, Y. Hu, X. Qi, F. Jiang, Z. Jiang and S. Tong (2020). "Epidemiological characteristics of 2143 pediatric patients with 2019 coronavirus disease in China." Pediatrics.

Guan, W.-j., Z.-y. Ni, Y. Hu, W.-h. Liang, C.-q. Ou, J.-x. He, L. Liu, H. Shan, C.-l. Lei and D. S. Hui (2020). "Clinical characteristics of coronavirus disease 2019 in China." New England Journal of Medicine.

Guo, Y.-R., Q.-D. Cao, Z.-S. Hong, Y.-Y. Tan, S.-D. Chen, H.-J. Jin, K.-S. Tan, D.-Y. Wang and Y. Yan (2020). "The origin, transmission and clinical therapies on coronavirus disease 2019 (COVID-19) outbreakan update on the status." Military Medical Research 7 (1): 1-10.

Henry, B. M. (2020). "COVID-19, ECMO, and lymphopenia: a word of caution." The Lancet Respiratory Medicine8 (4): e24.

Henry, B. M., M. H. S. de Oliveira, S. Benoit, M. Plebani and G. Lippi (2020). "Hematologic, biochemical and immune biomarker abnormalities associated with severe illness and mortality in coronavirus disease 2019 (COVID-19): a meta-analysis." Clin Chem Lab Med.

Hon, K., C. Leung, W. Cheng, P. Chan, W. Chu, Y. Kwan, A. Li, N. Fong, P. Ng and M. Chiu (2003). "Clinical presentations and outcome of severe acute respiratory syndrome in children." The Lancet 361 (9370): 1701-1703.

Huppert, F. A., E. M. Pinto, K. Morgan, M. CFAS and C. Brayne (2003). "Survival in a population sample is predicted by proportions of lymphocyte subsets." Mechanisms of ageing and development 124 (4): 449-451.

Liu, J., S. Li, B. Liang, X. Wang, H. Wang, W. Li, Q. Tong, J. Yi, L. Zhao, L. Xiong, C. Guo, J. Tian, J. Luo, J. Yao, R. Pang, H. Shen, C. Peng, T. Liu, Q. Zhang, J. Wu, L. Xu, S. Lu, B. Wang, Z. Weng, C. Han, H. Zhu, R. Zhou, H. Zhou, X. Chen, P. Ye, B. Zhu, L. Wang, W. Zhou, S. He, Y. He, S. Jie, P. Wei, J. Zhang, Y. Lu, W. Wang, L. Zhang, L. Li, F. Zhou, J. Wang, U. Dittmer, M. Lu, Y. Hu, D. Yang and X. Zheng (2020). "Longitudinal characteristics of lymphocyte responses and cytokine profiles in the peripheral blood of SARS-CoV-2 infected patients." EBioMedicine 55 : 102763.

Lotfi, M. and N. Rezaei (2020). "SARS-CoV-2: A comprehensive review from pathogenicity of the virus to clinical consequences." J Med Virol.

Maeda, I. S., N Iida, M Matsumoto, H Hashimoto, S Hirose, N (1999). "Relationship between CD4+/CD8+ $\mathrm{T}$ cell ratio and T cell activation in systemic lupus erythematosus." Scandinavian journal of rheumatology 28 (3): 166-170.

Margolick, J. B., A. Munoz, A. D. Donnenberg, L. P. Park, N. Galai, J. V. Giorgi, M. R. O'Gorman and J. Ferbas (1995). "Failure of T-cell homeostasis preceding AIDS in HIV-1 infection. The Multicenter AIDS Cohort Study." Nat Med 1 (7): 674-680.

McBride, J. A. and R. Striker (2017). "Imbalance in the game of T cells: what can the CD4/CD8 T-cell ratio tell us about HIV and health?" PLoS pathogens 13 (11).

Ng, C. T., L. M. Snell, D. G. Brooks and M. B. Oldstone (2013). "Networking at the level of host immunity: immune cell interactions during persistent viral infections." Cell Host Microbe 13 (6): 652-664.

Ni, M., F. B. Tian, D. D. Xiang and B. Yu (2020). "Characteristics of inflammatory factors and lymphocyte subsets in patients with severe COVID-19." J Med Virol.

Reker-Hadrup, S., J. Strindhall, T. Kollgaard, T. Seremet, B. Johansson, G. Pawelec, P. Strat and A. Wikby (2006). "Longitudinal studies of clonally expanded CD8 T cells reveal a repertoire shrinkage predicting 
mortality and increased number of dysfunctional cytomegalovirus-specific T cells in the elderly." J Immunol 176 (4): 2645-2653.

Saghazadeh, A. and N. Rezaei (2020). "Immune-epidemiological parameters of the novel coronavirus-a perspective." Expert Review of Clinical Immunology: 1-6.

Simpson, S., F. U. Kay, S. Abbara, S. Bhalla, J. H. Chung, M. Chung, T. S. Henry, J. P. Kanne, S. Kligerman and J. P. Ko (2020). "Radiological Society of North America Expert Consensus Statement on Reporting Chest CT Findings Related to COVID-19. Endorsed by the Society of Thoracic Radiology, the American College of Radiology, and RSNA." Radiology: Cardiothoracic Imaging 2 (2): e200152.

Sohrabi, C., Z. Alsafi, N. O'Neill, M. Khan, A. Kerwan, A. Al-Jabir, C. Iosifidis and R. Agha (2020). "World Health Organization declares global emergency: A review of the 2019 novel coronavirus (COVID19)." International Journal of Surgery.

Sun, D., H. Li, X.-X. Lu, H. Xiao, J. Ren, F.-R. Zhang and Z.-S. Liu (2020). "Clinical features of severe pediatric patients with coronavirus disease 2019 in Wuhan: a single center's observational study." World Journal of Pediatrics: 1-9.

Tang, X., C. Wu, X. Li, Y. Song, X. Yao, X. Wu, Y. Duan, H. Zhang, Y. Wang and Z. Qian (2020). "On the origin and continuing evolution of SARS-CoV-2." National Science Review.

Wang, D., B. Hu, C. Hu, F. Zhu, X. Liu, J. Zhang, B. Wang, H. Xiang, Z. Cheng and Y. Xiong (2020). Clinical characteristics of 138 hospitalized patients with 2019 novel coronavirus-infected pneumonia in Wuhan, China. JAMA [Internet]. 2020 Feb [cited 2020 Mar 23]; 323 (11): 1061-9.

Wang, F., J. Nie, H. Wang, Q. Zhao, Y. Xiong, L. Deng, S. Song, Z. Ma, P. Mo and Y. Zhang (2020). "Characteristics of Peripheral Lymphocyte Subset Alteration in COVID-19 Pneumonia." J Infect Dis 221 (11): 1762-1769.

Yang, A. P., H. M. Li, W. Q. Tao, X. J. Yang, M. Wang, W. J. Yang and J. P. Liu (2020). "Infection with SARS-CoV-2 causes abnormal laboratory results of multiple organs in patients." Aging (Albany NY) 12 .

Yazdanpanah, F., M. R. Hamblin and N. Rezaei (2020). "The immune system and COVID-19: Friend or foe?" Life Sci: 117900.

Zhang, W., Y. Zhao, F. Zhang, Q. Wang, T. Li, Z. Liu, J. Wang, Y. Qin, X. Zhang and X. Yan (2020). "The use of anti-inflammatory drugs in the treatment of people with severe coronavirus disease 2019 (COVID-19): The experience of clinical immunologists from China." Clinical Immunology: 108393.

Table 1. The patients' laboratory findings and blood lymphocyte subsets of children with COVID-19

\begin{tabular}{llll}
\hline Parameter & Mild $($ Mean \pm SD) & Severe $($ Mean \pm SD) & P value \\
\hline White blood cell count $(\times 109$ cells per L) & $8.8 \pm 6.1$ & $8.6 \pm 4.3$ & 0.4 \\
Neutrophil count $(\times 109$ cells per L) & $5.8 \pm 5.0$ & $6.2 \pm 3.9$ & 0.69 \\
Lymphocyte count $(\times 109$ cells per L) & $2.3 \pm 2.2$ & $1.6 \pm 0.9$ & 0.05 \\
Platelet count $(\times 109$ cells per L) & $272.5 \pm 159$ & $270 \pm 156$ & 0.9 \\
Red Blood Cells $(\times 109$ cells per L) & $4.4 \pm 0.7$ & $4.4 \pm 0.1$ & 0.19 \\
Hemoglobin $($ g.dL $)$ & $11.9 \pm 1.9$ & $11.1 \pm 2.6$ & 0.32 \\
CD4 ${ }^{+}$T cells \% & $34.8 \pm 11.2$ & $32 \pm 8.6$ & 0.9 \\
CD8 ${ }^{+}$T cells \% & $27.7 \pm 10.1$ & $31.3 \pm 8.1$ & 0.9 \\
C-reactive protein $($ mg.L)* & $14(4-62)$ & $34(7.2-69)$ & 0.22 \\
Erythrocyte sedimentation rate $(\mathrm{mm} / \mathrm{h})^{*}$ & $22(14-41)$ & $40.5(23.5-58)$ & 0.03 \\
\hline
\end{tabular}

*Median (Interquartile range) 
Table 2. The blood lymphocyte subsets of children with COVID-19

\begin{tabular}{lllllll}
\hline COVID-19 Severity & & CD4 ${ }^{+}$T cells & CD4 ${ }^{+} \mathrm{T}$ cells & $\mathrm{CD}^{+} \mathrm{T}$ cells & $\mathrm{CD}^{+} \mathrm{T}$ cells & $\mathrm{CD}$ \\
\hline \multirow{3}{*}{ Mild } & & Below normal range & Within normal range & Above normal range & Below normal range & With \\
& $\mathrm{N}$ & 10 & 21 & 3 & 4 & 24 \\
Severe & $\%$ & 29 & 62 & 9 & 12 & 70 \\
& $\mathrm{~N}$ & 8 & 13 & 0 & 5 & 67 \\
Total & $\%$ & 3 & 92 & 0 & 5 & 38 \\
& $\mathrm{~N}$ & 18 & 34 & 3 & 9 & 69 \\
\hline
\end{tabular}

Table 3. Demographic and laboratory findings of children with COVID-19 according to different $\mathrm{CD} 4^{+} / \mathrm{CD} 8^{+} \mathrm{T}$ cells ratio

\begin{tabular}{|c|c|c|c|}
\hline \multicolumn{2}{|l|}{ Parameter } & \multirow{3}{*}{$\begin{array}{l}\mathrm{CD}^{+} / \mathrm{CD} 8^{+} \mathrm{T} \text { cells ratio } \\
<1(\mathrm{~N}=19) \\
\mathrm{N}\end{array}$} & \multirow{3}{*}{$\begin{array}{l}\mathrm{CD}^{+} / \mathrm{CD} 8^{+} \mathrm{T} \text { cells rati } \\
<1(\mathrm{~N}=19) \\
\%\end{array}$} \\
\hline & & & \\
\hline & & & \\
\hline Mild & & 9 & 47 \\
\hline Severe & & 10 & 53 \\
\hline \multirow[t]{2}{*}{ Sex } & Male & 12 & 63 \\
\hline & Female & 7 & 37 \\
\hline \multirow[t]{4}{*}{ Age } & $<1$ year & 1 & 5 \\
\hline & 1 to 5 year & 5 & 26 \\
\hline & 5 to 10 year & 6 & 32 \\
\hline & 10 to 15 year & 7 & 37 \\
\hline Death & & 2 & 11 \\
\hline Underlying disease & & 10 & 53 \\
\hline Abnormal CT findings & & 10 & 53 \\
\hline ICU admission & & 4 & 21 \\
\hline Invasive mechanical ventilation & & 2 & 11 \\
\hline \multirow{3}{*}{ White blood cell count $(\times 109$ cells per $\mathrm{L})$} & Below normal range & 3 & 16 \\
\hline & Within Normal range & 13 & 53 \\
\hline & Above normal range & 3 & 16 \\
\hline \multirow[t]{3}{*}{ Neutrophil count $(\times 109$ cells per L) } & Below normal range & 3 & 16 \\
\hline & Within Normal range & 11 & 58 \\
\hline & Above normal range & 5 & 26 \\
\hline \multirow[t]{3}{*}{ Lymphocyte count $(\times 109$ cells per L) } & Below normal range & 6 & 32 \\
\hline & Within Normal range & 13 & 53 \\
\hline & Above normal range & 0 & 0 \\
\hline \multirow[t]{3}{*}{ Platelet count $(\times 109$ cells per $\mathrm{L})$} & Below normal range & 5 & 26 \\
\hline & Within Normal range & 12 & 63 \\
\hline & Above normal range & 2 & 11 \\
\hline C-reactive protein (mg.L) & Above normal range & 15 & 79 \\
\hline Erythrocyte sedimentation rate $(\mathrm{mm} / \mathrm{h})$ & Above normal range & 14 & 74 \\
\hline
\end{tabular}

\section{Hosted file}

image1.emf available at https://authorea.com/users/339735/articles/465883-effects-ofcoronavirus-disease-2019-covid-19-on-peripheral-blood-lymphocytes-and-their-subsets- 
in-children-imbalanced-cd4-cd8-t-cell-ratio-and-disease-severity

\section{Hosted file}

image2.emf available at https://authorea.com/users/339735/articles/465883-effects-ofcoronavirus-disease-2019-covid-19-on-peripheral-blood-lymphocytes-and-their-subsetsin-children-imbalanced-cd4-cd8-t-cell-ratio-and-disease-severity

$\mathrm{P}$ value $=0.3 \mathrm{P}$ value $=0.4 \mathrm{P}$ value $=0.039$

\section{Hosted file}

image3.emf available at https://authorea.com/users/339735/articles/465883-effects-ofcoronavirus-disease-2019-covid-19-on-peripheral-blood-lymphocytes-and-their-subsetsin-children-imbalanced-cd4-cd8-t-cell-ratio-and-disease-severity

Figure 1. Profile of $\mathrm{CD} 4^{+} \mathrm{T}$ cells, $\mathrm{CD} 8^{+} \mathrm{T}$ cells and $\mathrm{CD} 4^{+} / \mathrm{CD} 8^{+} \mathrm{T}$ cells ratio in lymphocytes in children with COVID-19 